guards may provide only an illusion of protection". On nuclear theft, the Report say's "the risks are real and will tend to increase with the further spread of nuclear technology".

The moral argument against uranium mining and export, applied internationally, which says that Australia should not contribute further to the world's problems, has cut no ice with the government, which paints such protests as being against the national interest measured in terms of overseas earnings and jobs. In response, the environmentalists point to the Report's economic analysis which concluded that the contribution of the potential income from the Ranger deposit to national income is relatively small-. only $0.1 \%$ in 1980-81, rising to about $0.5 \%$ in 1990-91, and declining to $0.4 \%$ by the end of the century.

On the question of disposal of radioactive wastes, the Report emphasises that, despite the claims of the nuclear industry, "the whole problem is one of first-rate international importance" and urges that "some internationally acceptable system (be) established for the disposal of high-level wastes, and international supervision of what is done".

\section{Expert witnesses?}

The Commissioners made a damaging but probably long overdue attack on the credibility of so-called "expert witnesses", many of whom, it is clear, they heard only with patient sufferance: "In considering the evidence", they say,

we have found that many wildly exaggerated statements are made about the risks and dangers of nuclear energy production by those opposed to it. What has surprised us more is a lack of objectivity in not a few of those in favour of it, including distinguished scientists.

From the published list of witnesses, it is not hard to identify the latter group.

In noting the strong emotional overtones of the evidence, the Commissioners found that "distinguished nuclear scientists" were to be found flatly opposed to each other, but "the final decisions should rest with the ordinary man and not be regarded as the preserve of any group of scientists or experts, however idistinguished". And in a further attempt to prick the hardened skins of the nuclear lobby, the Commissioners say that "a few of the publicists for nuclear development characterise their opponents as lobbyists or dissidents, or worse". They go on:

We would wish to make it quite plain that before us the opposition has come from a wide cross-section of the general community, and we would not be prepared to conclude that their motives and methods are any less worthy or proper, or intelli-

\section{Fox findings in full}

The Fox Report's findings, reflecting the summarised cvidence and its analysis of that evidence, may remain its most lasting contribution to an ever-widening debate. In full, they read as follows:

These findings and recommendations are to be read and understood in the context of the Report as a whole and with particular reference to the sections of the Report in which they are respectively discussed.

1. The hazards of mining and milling uranium, if those activities are properly regulated and controlled, are not such as to justify a decision not to develop Australian uranium mines.

2. The hazards involved in the ordinary operations of nuclear power reactors, if those operations are properly regulated and controlled. are not such as to justify a decision not to mine and sell Australian uranium.

3. The nuclear power industry is unintentionally contributing to an increased risk of nuclear war. This is the most serious hazard associated with the industry. Complete evaluation of the extent of the risk and assessment of what course should be followed to reduce it involve matters of national security and international relations which are beyond the ambit of the Inquiry. We suggest that the questions involved are of such importance that they be resolved by Parliament. In Chapters 15 and 16 we have gone as far as the terms of reference and the evidence permit in examining the courses open and in making suggestions.

4. Any development of Australian uranium mines should be strictly regulated and controlled, for the purposes mentioned in Chapter 16.

5. Any decision about mining for uranium in the Northern Territory should be postponed until the Second Report of this Commission is presented. 6. A decision to mine and sell uranium should not be made unless the Commonwealth Government ensures that the Commonwealth can at any time, on the basis of considerations of the nature discussed in this Report, immediately terminate those activities. permanently. indefinitely or for a specified period.

7. Policy respecting Australian uranium exports, for the time being at least. should be based on a full recognition of the hazards dangers and problems of and associated with the production of nuclear energy, and should therefore seek to

gently conceived, than, in general, are those of the supporters of nuclear development.

\section{Political postscript}

The 300 or so people at the Mary Kathleen mine in Queensland, the only active uranium producer at the moment, are dependent on the mine's continuance for employment and arc now assured of a joh for a few ycars while the existing contracts are fulfilled. But the investment-led recovery of the national economy, in which the hoped-for expansion of the mining industry played such a key role, has been thrown into confusion since the Fox Report and the decision to export. The massive $17 \frac{1}{2} \%$ devaluation at the limit or restrict expansion of that production.

8. No sales of Australian uranium should take place to any country not party to the Non-Proliferation Treaty. Export should be subject to the fullest and most effective safeguards agreements. and be supported by fully adequate backup agreements applying to the entire civil nuclear industry in the country supplied. Australia should work towards the adoption of this policy by other suppliers.

9. A permanent Uranium Advisory Council. to include adequate representation of the people, should be established immediatcly to advise the Government. but with a duty also to report at least annually to the Parliament, with regard to the export and use of Australian uranium, having in mind in particular the hazards, dangers and problems of and associated with the production of nuclear energy.

10. The Government should immediately explore what steps it can take to assist in reducing the hazards, dangers and problems of and associated with the production of nuclear energy.

11. Policy with regard to the export of uranium should be the subject of regular revicw.

12. A national energy policy should be developed and reviewed regularly.

13. Steps should be taken immediately to institute full and energetic programs of research and development into (a) liquid fuels to replace petroleum and (b) encrgy sources other than fossil fuels and nuclear fission.

14. A program of energy conservation should be instituted nationally.

15. The policy of the Government should take into account the importance to Australia, and the countries of the world, of the position of developing countrics concerning energy needs and resources.

Our final recommendation takes account of what we understand to be the policy of the Act under which the Inquiry was instituted. It is simply that there should be ample time for public consideration of this Report, and for debate upon it. We therefore recommend that no decision be taken in relation to the foregoing matters until a reasonable time has elapsed and there has been an opportunity for the usual democratic processes to function, including in this respect, parliamentary debate. end of November, followed in only 9 days by a $2 \%$ revaluation and mostly inconsequential tarriff cuts, have rocked the government and its traditional supporters in industry and the press.

The style of Mr Fraser was to purvey a well-controlled image of businessman-like decisiveness, repairing the damage allegedly caused by $\mathrm{Mr}$ Whitlam's Labor administration. Suddenly, and by its own hand. the government seems vulnerable. If a uranium debate really gets off the ground in 1977 following the Fox Report No. 2, it is anyone's guess as to whether the government will have things all its own way as it did with Report No. 1. 